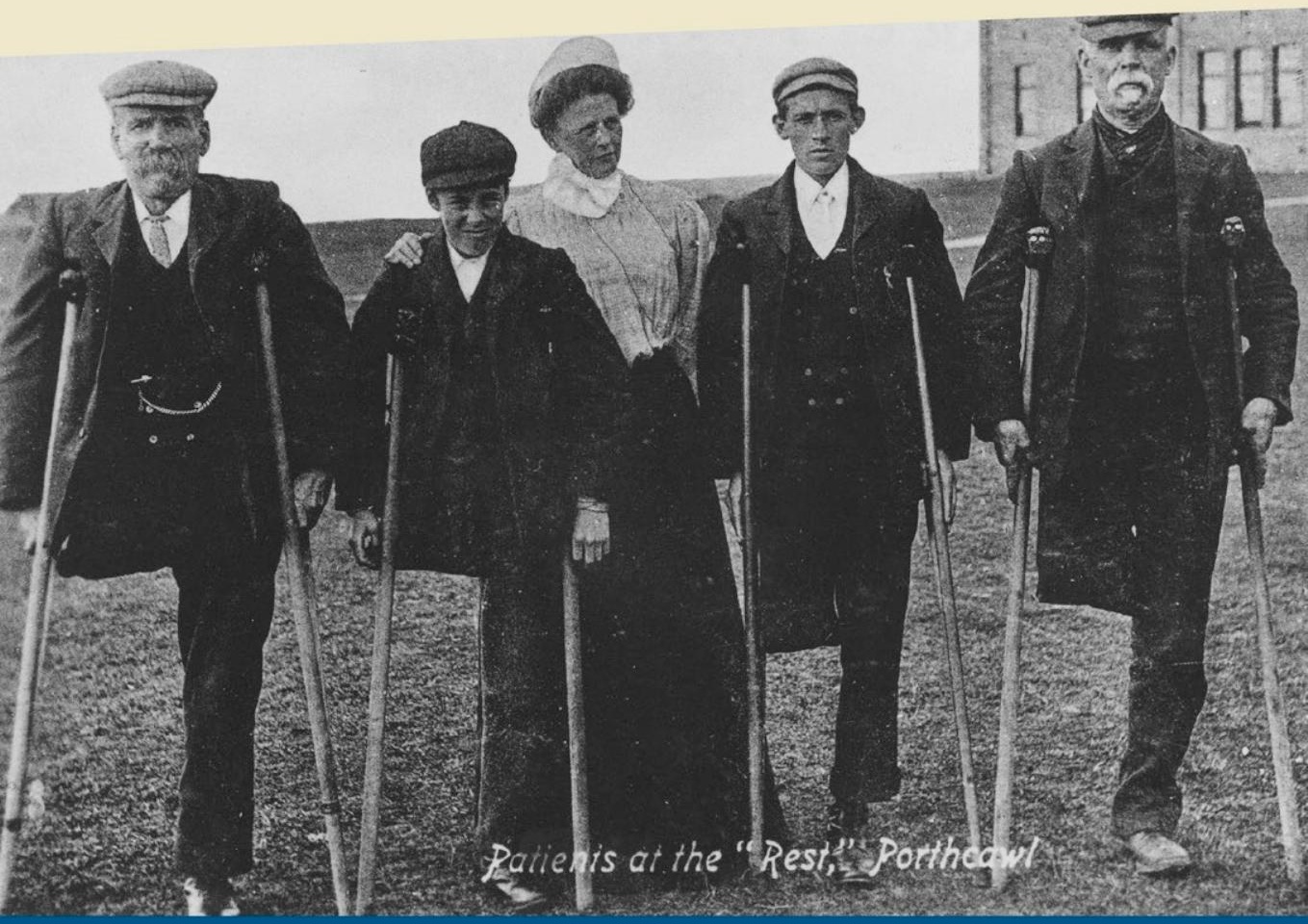

\title{
Disability in industrial Britain
}

A cultural and literary history of impairment in the coal industry,

$1880-1948$

KIRSTI BOHATA, ALEXANDRA JONES, MIKE MANTIN AND STEVEN THOMPSON 


\section{DISABILITY IN INDUSTRIAL BRITAIN}

\section{MANCHESTER 1824}

Manchester University Press 
Kirsti Bohata, Alexandra Jones, Mike Mantin, and Steven Thompson - 9781526124326 Downloaded from manchesterhive.com at $04 / 26 / 2023$ 12:56: 05PM 


\section{DISABILITY IN INDUSTRIAL BRITAIN}

\section{A CULTURAL AND LITERARY HISTORY OF IMPAIRMENT IN THE COAL INDUSTRY, I 880-I 948}

Kirsti Bohata, Alexandra Jones, Mike Mantin and Steven Thompson

Manchester University Press 
The rights of Kirsti Bohata, Alexandra Jones, Mike Mantin and Steven Thompson to be identified as the authors of this work have been asserted by them in accordance with the Copyright, Designs and Patents Act 1988.

This electronic version has been made freely available under a Creative Commons (CC-BY-NC-ND) licence, thanks to the support of the Wellcome Trust, which permits non-commercial use, distribution and reproduction provided the authors and Manchester University Press are fully cited and no modifications or adaptations are made. Details of the licence can be viewed at https://creativecommons.org/licenses/by-nc-nd/4.0/.

Published by Manchester University Press

Altrincham Street, Manchester M1 7JA

www.manchesteruniversitypress.co.uk

British Library Cataloguing-in-Publication Data

A catalogue record for this book is available from the British Library

ISBN 9781526124319 hardback

ISBN 9781526124326 open access

First published 2020

The publisher has no responsibility for the persistence or accuracy of URLs for any external or third-party internet websites referred to in this book, and does not guarantee that any content on such websites is, or will remain, accurate or appropriate.

\section{Cover image:}

Patients at Porthcawl Rest home.

Richard Burton Archives, Swansea University

Typeset

by Toppan Best-set Premedia Limited 